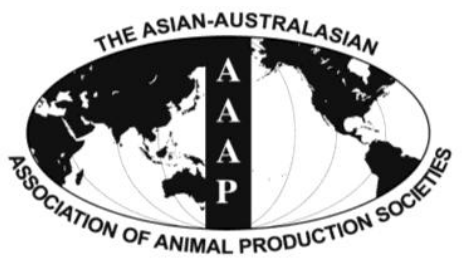

Asian Australas. J. Anim. Sci.

Vol. 26, No. 12 : 1717-1725 December 2013

http://dx.doi.org/10.5713/ajas.2013.13165

www.ajas.info

pISSN 1011-2367 elSSN 1976-5517

\title{
Grazing Behavior and Locomotion of Young Bulls Receiving Different Nutritional Plans in a Tropical Pasture
}

\author{
E. E. L. Valente ${ }^{1, *}$, M. F. Paulino², E. Detmann², S. C. Valadares Filho ${ }^{2}$, \\ M. L. Chizzotti ${ }^{2}$, A. G. Silva ${ }^{2}$, and I. F. S. Maciel $^{2}$ \\ ${ }^{1}$ Department of Animal Science, Universidade Estadual do Oeste do Paraná, Marechal Cândido Rondon, \\ 85960-000, PR, Brazil
}

\begin{abstract}
The objectives of this study were to compare visual observation and an electronic grazing time method and to evaluate the effects of nutritional plans on intake, grazing behavior and horizontal and vertical locomotion of young bulls in a tropical pasture. Thirty-nine Nellore young bulls with an average body weight of $345 \pm 9.3 \mathrm{~kg}$ kept in pasture were used. The experimental treatments consisted of: restricted: animals kept in a plot with a low mass of forage receiving mineral mixture only; control: animals receiving mineral mixture only; HPHC: a high protein and high carbohydrate supplement; HPLC: a high protein and low carbohydrate supplement; LPHC: a low protein and high carbohydrate supplement; LPLC: a low protein and low carbohydrate supplement. GPS collars equipped with activity sensors were used. Information about head position, latitude, longitude and altitude were recorded. Daytime grazing behavioral patterns monitored by a continuous focal animal recording method was compared to behavior estimated by the activity sensor. Feed intake was estimated by a marker method. The Restricted group presented lower $(\mathrm{p}<0.05)$ intake of dry matter and TDN. However, difference in dry matter intake was not found $(\mathrm{p}>0.05)$ between non-supplemented and supplemented animals. Difference was not found $(\mathrm{p}>0.05)$ in daytime grazing time obtained by visual observation or the activity sensor method. The restricted group showed longer $(\mathrm{p}<0.05)$ grazing time $(9.58 \mathrm{~h} / \mathrm{d})$ than other groups, but difference was not found $(\mathrm{p}>0.05)$ in the grazing time between Control $(8.35 \mathrm{~h} / \mathrm{d})$ and supplemented animals $(8.03 \mathrm{~h} / \mathrm{d})$. The Restricted group presented lower $(\mathrm{p}<0.05)$ horizontal locomotion distance $(2,168 \mathrm{~m} / \mathrm{d})$ in comparison to other groups $(2,580.6 \mathrm{~m} / \mathrm{d})$. It can be concluded that the use of activity sensor methods can be recommended due to their being similar to visual observation and able to record $24-\mathrm{h} / \mathrm{d}$. While supplements with high carbohydrates reduce pasture intake, they do not change grazing behavior. Moderate supplementation (until $50 \%$ of protein requirement and $30 \%$ of energy requirement) of beef cattle on tropical pasture has no effect on daily locomotion. (Key Words: Activity, Cattle, GPS, Sensor, Supplement)
\end{abstract}

\section{INTRODUCTION}

The use of electronic equipment to monitor cattle grazing has been used to study energy expenditure in physical activities (Brosh et al., 2010) and animal behavior as well as interaction with the environment (Handcock et al., 2009). Spatial distribution of cattle and pasture utilization are heterogeneous. This heterogeneity may derive from features of the landscape such as topography, forage availability and quality, and also from features of the management system and supplementation (Ungar et al.,

\footnotetext{
* Corresponding Author: Eriton Egidio Lisboa Valente. E-mail: eritonvalente@yahoo.com.br

${ }^{2}$ Department of Animal Science, Universidade Federal de Viçosa (UFV), Viçosa, MG, 36570-000 Brazil.

Submitted Mar. 21, 2013; Accepted Jul. 9, 2013; Revised Aug. 1, 2013
}

2010).

Historically, it has been very difficult to study behavior and the spatial distribution of animals. The measurement of animal behavior through the visual observation method is laborious and presents inherent limitations due to errors associated with the fatigue of the observer, physical obstacles, the effect of proximity of the observer on animals, weather, and daylight. Nowadays, the global positioning system (GPS) is commonly employed in animal research (Trotter et al., 2010). However, the use and integration of this technology is still under development (Handcock et al., 2009). GPS receivers in a lightweight collar or harness can be deployed for extended periods with little effect on animal behavior. Units derive coordinates from an internal receiver tracking an array of earth-orbiting satellites. Coordinates are stored in onboard memory for later retrieval 
or relayed to external memory (Johnson and Ganskopp, 2008). Thus it is possible get information of the locomotion (horizontal and vertical) of the animals.

Cattle try to minimize expended energy in grazing activity and maximize energy returns. However, they do not always optimize nutrient intake during a meal or on a daily basis (Distel et al., 1995). This occurs mostly due to diet effects (Ganskopp and Bohnert, 2009). Feed intake from cattle grazing is influenced mainly by pasture structure and by supplementation (Baudracco et al., 2010). In addition, supplementation affects forage intake, pasture utilization efficiency (Valente et al., 2011a), and animal behavior (Casagrande et al., 2011). However, the intake and utilization of roughage is affected by supplement composition due to associative effects (Souza et al., 2010), which are influenced by the amount of supplement intake (Valente et al., 2011a). When cattle receive supplements, reduction of the grazing period may occur (Bargo et al., 2003). Thus, many studies observed that quantity and composition of supplements affect dry matter intake and grazing behavior though little research has simultaneously addressed these effects.

The objectives of this study were to compare visual observation and electronic methods of evaluation of grazing time and to evaluate the effects of nutritional planning on intake, grazing behavior and the horizontal and vertical locomotion of young bulls in a tropical pasture.

\section{MATERIAL AND METHODS}

\section{Animals, experiment designed and diets}

The experimental protocol and procedures were approved by the Universidade Federal de Viçosa Animal Care and Use Committee.

This experiment was carried out at the beef cattle facility of the Universidade Federal de Viçosa, in Viçosa, MG, Brazil $\left(20^{\circ} 45^{\prime} \mathrm{S} 42^{\circ} 52^{\prime} \mathrm{W}\right)$. The experimental area is located in a hilly area at an altitude of $670 \mathrm{~m}$ with some trees to provide shadow. This study was carried out between January and April, 2011. Throughout the measurement period, the average minimum and maximum temperatures were $19.8^{\circ}$ and $29.2^{\circ} \mathrm{C}$ in January, $18.9^{\circ}$ and $30.9^{\circ} \mathrm{C}$ in February, $19.1^{\circ}$ and $27.5^{\circ} \mathrm{C}$ in March, $17.3^{\circ}$ and $26.9^{\circ} \mathrm{C}$ in April. There were $187 \mathrm{~mm}$ of rainfall in January, $85 \mathrm{~mm}$ in February, $284 \mathrm{~mm}$ in March and $57 \mathrm{~mm}$ in April. Animals were allowed a period of $30 \mathrm{~d}$ of adaptation to the diet and management and a 90-d experimental period for evaluation of intake, movement and behavior.

Thirty-nine Nellore young bulls with an average body weight of $345 \pm 9.3 \mathrm{~kg} \mathrm{SE}$ and between the ages of 15 and 17 months were used. The animals were divided into 6 groups. The Restricted group was composed of four animals kept in a pasture with low forage mass (about 1,500 kg DM/ha). The average forage mass of the Restricted group was controlled by using an area ranging from 0.5 to 1 ha. The remaining animals were distributed in two-ha pastures (seven animals/plot). Five nutritional plans were randomly assigned to animals in pasture: Control: mineral mixture only; HPHC: high protein and high carbohydrate supplement; HPLC: high protein and low carbohydrate supplement; LPHC: low protein and high carbohydrate supplement; LPLC: low protein and low carbohydrate supplement (Table 1). About 50 and $25 \%$ of the crude protein $(\mathrm{CP})$ requirement were supplied by high and low

Table 1. Ingredient (as-fed basis) and chemical composition (\% DM basis) of supplements and pastures

\begin{tabular}{|c|c|c|c|c|c|c|c|c|}
\hline \multirow{2}{*}{ Ingredients } & \multicolumn{6}{|c|}{ Nutritional plan $^{1}$} & \multirow{2}{*}{ Pasture $^{2}$} & \multirow{2}{*}{ Pasture $2^{3}$} \\
\hline & Restrict & Control & HPHC & HPLC & LPHC & LPLC & & \\
\hline Corn & - & - & 55.0 & 0.0 & 83.5 & 53.0 & & \\
\hline Corn gluten & - & - & 3.0 & 20.0 & 0.0 & 14.0 & & \\
\hline Soybean meal & - & - & 37.0 & 70.0 & 12.0 & 24.0 & & \\
\hline Urea/AS ${ }^{4}$ & - & - & 1.0 & 2.0 & 0.5 & 1.0 & & \\
\hline $\mathrm{MM}^{5}$ & 100 & 100 & 4.0 & 8.0 & 4.0 & 8.0 & & \\
\hline \multicolumn{9}{|c|}{ Chemical composition $(\%)$} \\
\hline Dry matter & & & 87.1 & 89.5 & 85.8 & 87.0 & 20.5 & 21.3 \\
\hline Organic matter & & & 89.3 & 87.4 & 88.4 & 85.8 & 91.9 & 91.9 \\
\hline Crude protein & & & 29.2 & 55.3 & 15.4 & 29.5 & 10.6 & 10.7 \\
\hline NDFap $^{6}$ & & & 8.7 & 10.2 & 7.4 & 9.2 & 62.7 & 61.6 \\
\hline Ether extract & & & 2.6 & 1.5 & 3.0 & 2.4 & 1.2 & 1.2 \\
\hline $\mathrm{NFC}^{7}$ & & & 46.2 & 23.3 & 57.2 & 43.6 & 17.4 & 17.9 \\
\hline \multirow{2}{*}{\multicolumn{9}{|c|}{$\begin{array}{l}{ }^{1} \mathrm{HPHC}=\text { High protein and high carbohydrate supplement; HPLC }=\text { High protein and low carbohydrate supplement; LPHC = Low protein and hig } \\
\text { carbohydrate supplement; LPLC = Low protein and low carbohydrate supplement. }\end{array}$}} \\
\hline & & & & & & & & \\
\hline \multirow{2}{*}{\multicolumn{9}{|c|}{$\begin{array}{l}{ }^{2} \text { Obtained by hand plucked sampling to restrict group. }{ }^{3} \text { Obtained by hand plucked sampling to the other groups } \\
{ }^{4} \text { Urea+ammonia sulfate }(9: 1) \text {. }\end{array}$}} \\
\hline & & & & & & & & \\
\hline \multicolumn{9}{|c|}{$\begin{array}{l}{ }^{4} \text { Urea+ammonia sulfate (9:1). } \\
{ }^{5} \text { Mineral mixture; composition: calcium, } 8.7 \% \text {; phosphor, } 9.0 \% \text {; sulfur, } 9.0 \% \text {; sodium, } 18.7 \% \text {, zinc, } 2,400.00 \mathrm{mg} / \mathrm{kg} \text {; copper, } 800.00 \mathrm{mg} / \mathrm{kg} \text {; manganese, } \\
1,600.00 \mathrm{mg} / \mathrm{kg} \text {; iodine, } 40.00 \mathrm{mg} / \mathrm{kg} \text {; cobalt, } 8.00 \mathrm{mg} / \mathrm{kg} \text {; selenium, } 8.16 \mathrm{mg} / \mathrm{kg} \text {. }\end{array}$} \\
\hline
\end{tabular}


protein supplements respectively, and about 15 and $30 \%$ of the total digestible nutrients (TDN) requirement were supplied by high and low carbohydrate supplement, respectively. Every $28 \mathrm{~d}$, the amount of supplement was adjusted using the estimated protein and energy requirement as given in the Brazilian Table of Requirements of Beef Cattle (BR-CORTE, Valadares Filho et al., 2006). The weight gain in the adaptation period was used to first adjust the supplementation and the previous 28 days' weight gain to adjust in the other periods. The animals were fed, in groups, once a day at 11:00 h. Diet composition is presented in Table 1. In order to minimize possible effects of paddocks on experimental treatments, the animals were rotated among the five two-ha paddocks every seven days. The pasture was covered by signal grass (Brachiaria decumbens).

\section{Behavior and locomotion measurement}

GPS collars (GPS_3300LR, Lotek; Ontario, Canada) attached to the neck were used to evaluate grazing behavior (Ungar et al., 2005) and horizontal and vertical locomotion distance (Brosh et al., 2010). Those GPS Collars recorded information about latitude, longitude and altitude. The data were downloaded weekly.

Horizontal and vertical locomotion distances were computed using Microsoft Excel (Microsoft Corporation) during 10-minute intervals. The time devoted to the horizontal and vertical distances covered was calculated on a daily basis. Animal movements were divided into a horizontal and vertical axis to estimate horizontal locomotion distance and vertical locomotion distance (Brosh et al., 2010)

The collar contained a head-down activity sensor that consists of a switch that opens or closes according to the head position. The contact closes and the collar registers a down position when the collar is at an angle $>7.5^{\circ}$ clockwise to perpendicular to the horizontal plane. The contact is opened when the collar angle is $>7.5^{\circ}$ anticlockwise. In the intermediate angle range of $\pm 7.5^{\circ}$ to perpendicular, the contact could be open or closed. The collar stores the percentage of time the sensor registers the down position during an activity sampling period. The collars were configured to register activity sensor (head position) every five minutes. The head-down position was considered as grazing activity.

Two animals from each group (12 animals) were trained to use the GPS collar. After $30 \mathrm{~d}$ of adaptation to the collar and management, the animals were monitored with the GPS collar for 48-h, by using two animals each time, each one from a different group. After 48-h recording data, the proceeding was repeated with animals from the other group. The schedule was: wk $1=$ six 48 -h data collected (one of each group); wk $2=$ repeated schedule of the wk 1 using other animals; wk 3 and 4 = data weren't collected; wk 5 and $6=$ repeated schedule of the wk 1 and 2; wk 7 and $8=$ data weren't collected; wk 9 and $10=$ repeated schedule of the wk 1 and 2. Thirty-six 48-h observations (six measures per group), 10368 GPS records and 20736 activity sensor records were collected between February and April.

The daytime grazing activity pattern was monitored for six day (each day in a different week), simultaneously with GPS collection data and through the continuous focal animal recording method using binoculars with a minimum range of $100 \mathrm{~m}$. Animals were previously trained with the equipment and to the presence of humans to reduce the effects of human activity on their normal behavior. Evaluation of behavior started at 06:00 $\mathrm{h}$ and finished at 18:00 h. Trained personnel observed animal behavior continuously in six hour shifts and recorded time activities of collar-attached animals. Activities were divided into grazing activities (time collecting forage) and non-grazing activities which include all regular cattle activities, except grazing, as for example rumination and idle.

To compare visual observation (human recording) and sensor activity methods (GPS recording), it was used data collected from 06:00 h to 18:00 h by both methods. Grazing time and other activities time (non-grazing time) were recorded as well.

\section{Experimental procedures and sampling}

Forage samples were randomly taken, each $28 \mathrm{~d}$, in order to evaluate the mass of forage per hectare. In each paddock, six forage samples were randomly selected $(0.5 \times$ $0.5 \mathrm{~m}$ ) and cut approximately one $\mathrm{cm}$ above the soil. After that, forage subsamples $(200 \mathrm{~g})$ were dried at $60^{\circ} \mathrm{C}$ for $72 \mathrm{~h}$ and ground to pass through a one-mm screen. Every seven days, a handle plucked sampling was performed simultaneously with the observation of the grazing behavior of the animals in order to obtain samples to evaluate the chemical composition of the forage consumed by the animals. All samples were dried at $60^{\circ} \mathrm{C}$ for $72 \mathrm{~h}$, ground to pass through one-mm screen sieve, and proportionally subsampled to a composite sample per month.

In order to evaluate forage intake and digestibility, a digestion trial (eight days) was performed in March. Fecal dry matter excretion was obtained by using chromic oxide as an external marker (16 g/d) which was packaged in a paper cartridge and directly introduced into the esophagus through a rubber tube. The animals received the marker once daily at 11:00 h for seven days. After five days of adaptation, fecal samples were collected at 15:00 $\mathrm{h}$ on the sixth day, at 11:00 $\mathrm{h}$ on the seventh day, and at 07:00 $\mathrm{h}$ on the eighth day of the digestion trial period. To evaluate individual intake of the supplement $16 \mathrm{~g} / \mathrm{d}$ of titanium dioxide was mixed in the supplement and offered to animals in the group. Indigestible neutral detergent fiber (NDF) was 
used as an internal marker to estimate pasture intake. Fecal samples were dried at $60^{\circ} \mathrm{C}$ for $72 \mathrm{~h}$, ground to pass through one-mm screen sieve, and proportionally sub-sampled to a composite sample.

\section{Chemical analysis}

Samples of forage, feces and supplement ingredients were analyzed for dry matter (DM, index no. 920.39), nitrogen compounds ( $\mathrm{N}$, index no. 954.01), ashes and ether extract (EE, index no. 920.39) as described by AOAC (Association of Official Analytical Chemists, 1990). For analysis of neutral detergent fiber (NDF), samples were treated with thermostable $\alpha$-amylase without sodium sulfite and corrected for ash residue (Mertens, 2002) and residual nitrogen compounds. The iNDF was evaluated using F57 (Ankon) bags and incubated in rumen by 288 hours (Valente et al., 2011b). Fecal samples were evaluated for chromium content by using atomic absorption methods (Willians et al., 1962).

Mass of forage samples obtained was analyzed for DM, as described before. The dry matter intake (DMI) was estimated by using the following equation:

$$
\begin{aligned}
\mathrm{DMI}(\mathrm{kg} / \mathrm{d})=\{[ & {[(\mathrm{FE} \times \mathrm{iNDF} \text { feces })} \\
& -\mathrm{iNDF} \text { supplement }] / \mathrm{iNDF} \text { forage }\}+\mathrm{SI}
\end{aligned}
$$

Where: FE is the fecal excretion $(\mathrm{kg} / \mathrm{d})$; iNDF feces is the concentration of iNDF in the feces $(\mathrm{kg} / \mathrm{kg})$; iNDF supplement is the amount of iNDF in the supplement $(\mathrm{kg})$; iNDF forage is the concentration of NDFi in the forage $(\mathrm{kg} / \mathrm{kg})$; and SI is the supplement intake $(\mathrm{kg})$.

\section{Statistical analysis}

The study was conducted under a completely randomized design using a $2 \times 2$ factorial arrangement plus two additional groups (two protein amounts and two carbohydrate amount plus one control group and one restricted intake group) and comparisons among treatment means were made by using contrasts (Table 2). Additionally, to verify if the grazing behavior was similar when using visual observation and sensor methods, linear regression was performed to test whether the intercept and slope were
Table 2. Distribution of coefficients for orthogonal contrasts used

\begin{tabular}{|c|c|c|c|c|c|c|}
\hline \multirow{2}{*}{ Contrasts $^{1}$} & \multicolumn{6}{|c|}{ Treatments } \\
\hline & Restrict & Control & HPHC & HPLC & LPHC & LPLC \\
\hline \multicolumn{7}{|c|}{ Orthogonal group } \\
\hline $\mathrm{R}$ & +5 & -1 & -1 & -1 & -1 & -1 \\
\hline $\mathrm{CT}$ & 0 & +4 & -1 & -1 & -1 & -1 \\
\hline $\mathrm{P}$ & 0 & 0 & +1 & +1 & -1 & -1 \\
\hline $\mathrm{C}$ & 0 & 0 & +1 & -1 & +1 & -1 \\
\hline $\mathrm{P} \times \mathrm{C}$ & 0 & 0 & +1 & -1 & -1 & +1 \\
\hline \multicolumn{7}{|c|}{ Additional contrast } \\
\hline $\mathrm{R} \times \mathrm{CT}$ & +1 & -1 & 0 & 0 & 0 & 0 \\
\hline
\end{tabular}
in the decomposition of the sum of squares

equal to zero and one, respectively. Significant difference was considered at $p<0.05$. Since the methods to estimate grazing behavior were similar, the sensor method was used to evaluate $24-\mathrm{h}$ grazing behavior. The data were analyzed using the GLM procedure of SAS version 9.1, (SAS Institute, Inc).

\section{RESULTS}

\section{Pasture characteristics and intake}

The forage mass in the restricted and other groups were 1.6 and 3.1, 1.7 and 3.5, 1.6 and 3.0, and 1.7 and 2.9 ton/ha of DM in January, February, March and April, respectively. The forage sampled by hand plucked sampling was considered high quality forage, presenting up to $10.7 \%$ of CP (Table 1) which is higher than the level of CP $(9 \%)$ suggested by Figueiras et al. (2010), that would optimize the forage use by grazing cattle. Although the restricted group had a high grazing pressure on pasture, the $\mathrm{CP}$ content in forage was similar to other groups (Table 1).

The animals from the restricted group presented lower $(\mathrm{p}<0.05)$ intake of DM and total digestible nutrients (TDN). However, a difference was not found $(\mathrm{p}>0.05)$ in the intake of DM between non-supplemented (Control) and supplemented animals. In addition, differences were not found ( $p>0.05)$ among supplemented animals in terms of

Table 3. Effect of nutritional plan (least square means, $\mathrm{kg} / \mathrm{d}$ ) on intake of supplement (SI), total dry matter (TDM), pasture dry matter

\begin{tabular}{|c|c|c|c|c|c|c|c|c|c|c|c|c|c|}
\hline \multirow{2}{*}{ Items } & \multicolumn{6}{|c|}{ Treatments } & \multirow{2}{*}{$\mathrm{RMSE}^{2}$} & \multicolumn{6}{|c|}{ p-value $^{1}$} \\
\hline & Restrict & Control & HPHC & HPLC & LPHC & LPLC & & $\mathrm{R}$ & CT & $\mathrm{P}$ & $\mathrm{C}$ & $\mathrm{P} \times \mathrm{C}$ & $\mathrm{R} \times \mathrm{CT}$ \\
\hline$\overline{\text { SI }}$ & - & - & 1.8 & 0.8 & 1.8 & 0.8 & - & - & - & - & - & - & - \\
\hline TDM & 4.1 & 6.0 & 7.8 & 7.8 & 7.3 & 8.1 & 1.5 & 0.001 & 0.014 & 0.867 & 0.508 & 0.512 & 0.086 \\
\hline PDM & 4.1 & 6.0 & 6.1 & 7.1 & 5.7 & 7.3 & 1.4 & 0.001 & 0.391 & 0.935 & 0.027 & 0.583 & 0.065 \\
\hline TDN & 2.3 & 3.5 & 5.0 & 4.8 & 4.5 & 5.1 & 0.9 & $<0.001$ & 0.003 & 0.787 & 0.586 & 0.299 & 0.090 \\
\hline
\end{tabular}
(PDM) and of total digestible nutrients (TDN)

${ }^{1} \mathrm{R}=$ Restrict group vs other groups, $\mathrm{CT}=$ Non-supplemented vs supplemented, $\mathrm{P}=$ Effect of protein amount, $\mathrm{C}=$ Effect of carbohydrate amount, $\mathrm{P} \times \mathrm{C}=$ Effect of interaction of protein and carbohydrate, $\mathrm{R} \times \mathrm{CT}=$ Restrict vs control.

${ }^{2}$ Root mean square error. 
intake of DM and TDN (Table 3). Although differences were not found $(p>0.05)$ in the intake of TDN among supplemented animals, nutritional plans with low carbohydrate (HPLC and LPLC) presented greater $(\mathrm{p}<0.05)$ pasture intake than nutritional plans with high carbohydrate (HPHC and LPHC) (Table 3).

The control animals had greater $(\mathrm{p}<0.05)$ pasture intake than animals from the restrict group and animals from supplemented groups. The animals that received low carbohydrate levels (HPLC and LPLC) had greater ( $\mathrm{p}<0.05)$ pasture intake than animals that received high carbohydrate levels (HPHC and LPHC) (Table 3).

\section{Grazing behavior and locomotion}

Differences were not found ( $p>0.05$ ) in daytime grazing time obtained by visual observation or activity sensor method. In the linear regression of observed and predicted behavior, the intercept was not different from zero $(p>0.05)$ and the slope was not different from one $(p>0.05)$. Moreover, the correlation coefficient between visual observation and activity sensor method was 0.96 (Figure 1).

Animals from the restricted group presented a longer $(\mathrm{p}<0.05)$ grazing time in a $24-\mathrm{h}$ period $(40 \%$ of the time) than the other groups (34\% of the time). In addition, animals from the restricted group presented longer $(\mathrm{p}<0.05)$ grazing time in a daytime period (06:00 $\mathrm{h}$ to $18: 00 \mathrm{~h}$ ) than the animals from the control group. However, differences were not found $(p>0.05)$ in grazing time in a daytime period among control and supplemented animals and between the nutritional plans (Table 4).

Differences were not found $(p>0.05)$ in the grazing time

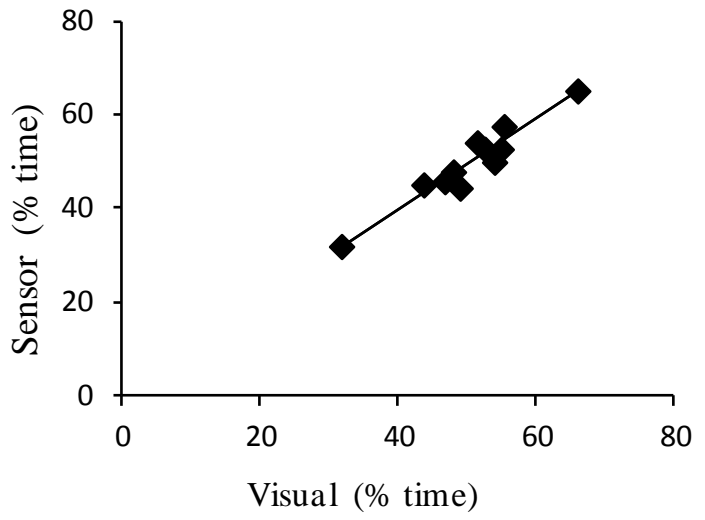

Figure 1. Percentage of daylight grazing time determined by visual observation and activity sensor. Visual observation values (X-axis) were compared with the activity sensor values (Y-axis) by linear regression analysis $\left(\mathrm{Y}=1.33+0.97 \mathrm{X}, \mathrm{r}^{2}=0.93\right)$. The intercept was not different from zero $(p>0.05)$ and the slope was not different from one $(\mathrm{p}>0.05)$.

in 06:00 $\mathrm{h}$ to 10:00 $\mathrm{h}$ period between the groups. Similarly to the 24-h grazing time, in the 10:00 $\mathrm{h}$ to14:00 $\mathrm{h}$ period and 06:00 $\mathrm{h}$ to18:00 $\mathrm{h}$ period, grazing times were longer $(p<0.05)$ in the restricted group in comparison to the other groups. In addition, animals from the restricted group presented longer $(\mathrm{p}>0.05)$ grazing time than animals from the control group. However, in the 10:00 h to14:00 h period and 06:00 $\mathrm{h}$ to18:00 $\mathrm{h}$ period, differences were not found ( $p>0.05)$ in grazing time between control and supplemented animals and among nutritional plans (Table 4). In daylight (06:00 h to18:00 h), about 55.4 and 43\% of time were used for grazing in restricted and others groups, respectively.

Table 4. Effect of nutritional plan (least square means, h) on grazing behavior measured by activities sensor

\begin{tabular}{|c|c|c|c|c|c|c|c|c|c|c|c|c|c|}
\hline \multirow{2}{*}{ Item $^{2}$} & \multicolumn{6}{|c|}{ Treatments } & \multirow{2}{*}{$\mathrm{RMSE}^{3}$} & \multicolumn{6}{|c|}{ p-value $^{1}$} \\
\hline & Restrict & Control & HPHC & HPLC & LPHC & LPLC & & $\mathrm{R}$ & $\mathrm{CT}$ & $\mathrm{P}$ & $\mathrm{C}$ & $\mathrm{P} \times \mathrm{C}$ & $\mathrm{R} \times \mathrm{CT}$ \\
\hline G24h & 9.6 & 8.4 & 7.7 & 8.5 & 7.8 & 8.2 & 1.0 & 0.002 & 0.490 & 0.821 & 0.171 & 0.634 & 0.037 \\
\hline $\mathrm{O} 24 \mathrm{~h}$ & 14.4 & 15.7 & 16.3 & 15.6 & 16.2 & 15.8 & 1.0 & 0.002 & 0.478 & 0.852 & 0.159 & 0.610 & 0.039 \\
\hline G6-10 & 1.4 & 1.2 & 1.3 & 1.3 & 1.2 & 1.6 & 0.4 & 0.709 & 0.583 & 0.604 & 0.234 & 0.365 & 0.524 \\
\hline G10-14 & 2.2 & 1.4 & 1.7 & 1.7 & 1.8 & 1.2 & 0.5 & 0.009 & 0.504 & 0.406 & 0.145 & 0.237 & 0.015 \\
\hline G14-18 & 3.1 & 2.7 & 2.0 & 2.4 & 2.0 & 2.6 & 0.5 & 0.004 & 0.063 & 0.865 & 0.037 & 0.641 & 0.243 \\
\hline G18-6 & 2.9 & 3.1 & 2.7 & 3.1 & 2.8 & 2.9 & 0.9 & 0.990 & 0.677 & 0.909 & 0.606 & 0.653 & 0.784 \\
\hline G6-18 & 6.7 & 5.3 & 5.0 & 5.4 & 5.0 & 5.3 & 0.8 & 0.001 & 0.739 & 0.835 & 0.289 & 0.984 & 0.009 \\
\hline O6-10 & 2.6 & 2.8 & 2.8 & 2.7 & 2.8 & 2.4 & 0.4 & 0.682 & 0.540 & 0.570 & 0.216 & 0.392 & 0.479 \\
\hline O10-14 & 1.8 & 2.6 & 2.3 & 2.4 & 2.2 & 2.8 & 0.5 & 0.012 & 0.481 & 0.445 & 0.162 & 0.208 & 0.017 \\
\hline O14-18 & 0.9 & 1.3 & 2.0 & 1.6 & 2.0 & 1.4 & 0.5 & 0.004 & 0.057 & 0.837 & 0.040 & 0.565 & 0.244 \\
\hline O18-6 & 9.1 & 9.0 & 9.3 & 8.9 & 9.2 & 9.1 & 0.9 & 0.983 & 0.720 & 0.943 & 0.605 & 0.653 & 0.807 \\
\hline O6-18 & 5.4 & 6.7 & 7.0 & 6.6 & 7.1 & 6.7 & 0.8 & 0.001 & 0.723 & 0.834 & 0.267 & 0.985 & 0.009 \\
\hline
\end{tabular}

${ }^{1} \mathrm{R}=$ Restrict group vs other groups, $\mathrm{CT}=$ Non-supplemented vs supplemented, $\mathrm{P}=$ Effect of protein amount, $\mathrm{C}=\mathrm{Effect}$ of carbohydrate amount, $\mathrm{P} \times \mathrm{C}=$ Effect of interaction of protein and carbohydrate, $\mathrm{R} \times \mathrm{CT}=$ Restrict vs control.

${ }^{2} \mathrm{G} 24 \mathrm{~h}=$ Grazing time in 24-h, O24h = Other activities time in 24-h, G6-10 = Grazing time between 06:00 h and 10:00 h, G10-14 = Grazing time between 10:00 $\mathrm{h}$ and 14:00 h, G14-18 = Grazing time between 14:00 h and 18:00 h, G18-6 = Grazing time between 18:00 h and 06:00 h, G6-18 = Grazing time between 06:00 h and 18::00 h, O6-10 = Other activities time between 06:00 h and 10:00 h, O10-14 = Other activities time between 10:00 h and 14:00 h, O14-18 = Other activities time between 14:00 h and 18:00 h, O18-6 = Other activities time between 18:00 h and 06:00 h, O6-18 = Other activities time between 06:00 $\mathrm{h}$ and 18:00 $\mathrm{h}$.

${ }^{3}$ Root mean square error. 
In the 14:00 $\mathrm{h}$ to18:00 $\mathrm{h}$ period, animals from the restricted group had longer $(p<0.05)$ grazing time than the control group and other groups. In the same period, the control animals had longer $(\mathrm{p}<0.05)$ grazing time than supplemented animals. The grazing time between 18:00 h and $06: 00 \mathrm{~h}$ (night period) were similar $(\mathrm{p}>0.05)$ to all groups.

The animals from the restricted group presented shorter $(\mathrm{p}<0.05)$ horizontal locomotion distances $(2,168 \mathrm{~m} / \mathrm{d})$ than the other groups $(2,580.6 \mathrm{~m} / \mathrm{d})$ (Table 5). However, differences were not found ( $>0.05)$ between control and supplemented animals. Similarly, differences were not found ( $p>0.05$ ) among the nutritional plans.

Differences were not found ( $p>0.05)$ in positive vertical locomotion distances among the groups and presented $363.3 \mathrm{~m} / \mathrm{d}$ (Table 5). Horizontal and vertical average locomotion speeds during grazing activities were 226.3 and $36.2 \mathrm{~m} / \mathrm{h}$ for the restricted group and 318.6 and $45.3 \mathrm{~m} / \mathrm{h}$ for other groups, respectively.

\section{DISCUSSION}

The daily pasture intake is a function of grazing time and the rate of forage intake, which is composed by bite rate and bite size. Pasture condition, especially the height, strongly affects the bite size (Hodgson, 1990). Therefore, pasture intake is reduced when forage mass is reduced (Gontijo Neto et al., 2006; Carloto et al., 2011). Some difficulty for apprehension and lower bite mass might occur in the restricted group due to the lower forage mass, which in turn, caused reduction in pasture intake (Table 3).

Supplement intake in moderate to high amounts may reduce pasture intake, maintaining or reducing the quantity of total DM intake due to the substitution effect (Valente et al., 2011a, 2013). The animals that received a high quantity of carbohydrate (HPHC and LPHC) presented lower pasture intake than animals that received a low quantity of carbohydrates (HPLC and LPLC) since carbohydrate may intensify the substitution effect (Souza et al., 2010). Although the reduction of pasture intake with supplementation has occurred, there was an average increase of $13 \%$ in TDN intake.

Most movements (behavior) of an individual animal can recruit the entire group of cattle (Ramseyer et al., 2009).
Thus, behavioral assessment of few individuals, into of a group, may estimate the behavior of entire group. Visual observation and activity sensor methods presented similar grazing behavior. Therefore, the activity sensor method use may be appropriate to study a group of cattle, even with using a sensor on part of the group, because it is less laborious and collects information in daylight and at night.

The time cattle spend eating is directly related to dry matter intake rate. When the forage mass is appropriate, intake rate is high and this is reflected in a faster satiety (lower time eating) and greater time of satiety (longer interval between meals). However, supplementation may affect both grazing time and pasture intake (Krysl and Hess, 1993). Bulls from the restricted group presented an average grazing time of $9.6 \mathrm{~h} / \mathrm{d}$, longer than eight to nine hours suggested by Hodgson (1990), which may indicate a limitation presented by the canopy to forage intake. The other groups had an average grazing time of $8.2 \mathrm{~h} / \mathrm{d}$, probably due to higher forage mass was reduced. Gontijo Neto et al. (2006) found grazing time of 6 to $10 \mathrm{~h} / \mathrm{d}$ with higher grazing time when the forage mass. Excessive grazing time, near to $10 \mathrm{~h} / \mathrm{d}$, indicates that the intake is not supplying metabolic requirements and non-nutritional factors are determining the intake. Grazing time is limited by time dedicated to non-grazing activities, for example, rumination. Normally, cattle spend 8 to $11 \mathrm{~h} / \mathrm{d}$ grazing, but this may vary in relation to forage mass and canopy structure (Di Marco and Aello, 1999). Celaya et al. (2008) found an increase in grazing time and a reduction of resting time with the reduction of sward height.

Although the restricted group had presented longer grazing time in daylight than other groups, grazing time at night was similar between the groups. This indicates that other factors, besides hunger-satiety and pasture characteristics also affect the grazing time and could limit the grazing. It seems that cattle do not have a preference for grazing in the first hours of the daylight in tropical conditions. Cattle usually start grazing after sunrise. In this study, the animals spent about $1.3 \mathrm{~h}$ grazing in 18:00 h to10:00 $\mathrm{h}$ period, evidencing low activity in the early morning. Casagrande et al. (2011) observed, in a tropical pasture, that less than $30 \%$ of cattle were grazing before 08:00 h, but after 09:00 h, 70\% of cattle were grazing. On the other hand, Gregorini et al. (2006) using Angus heifers

Table 5. Effect of nutritional plan (least square means, m) on horizontal and positive vertical locomotion

\begin{tabular}{|c|c|c|c|c|c|c|c|c|c|c|c|c|c|}
\hline & \multicolumn{6}{|c|}{ Treatments } & \multirow{2}{*}{$\mathrm{RMSE}^{4}$} & \multicolumn{6}{|c|}{ p-value ${ }^{1}$} \\
\hline & Restrict & Control & HPHC & HPLC & LPHC & LPLC & & $\mathrm{R}$ & $\mathrm{CT}$ & $\mathrm{P}$ & $\mathrm{C}$ & $\mathrm{P} \times \mathrm{C}$ & $\mathrm{R} \times \mathrm{CT}$ \\
\hline Horizontal $^{2}$ & $2,168.0$ & $2,709.4$ & $2,527.9$ & $2,438.4$ & $2,538.5$ & $2,688.9$ & 12.2 & 0.007 & 0.307 & 0.379 & 0.836 & 0.418 & 0.007 \\
\hline Vertical $^{3}$ & 346.7 & 381.2 & 348.3 & 339.7 & 373.3 & 390.4 & 10.5 & 0.273 & 0.360 & 0.058 & 0.824 & 0.504 & 0.150 \\
\hline
\end{tabular}

${ }^{1} \mathrm{R}=$ Restrict group vs other groups, $\mathrm{CT}=$ Non-supplemented versus supplemented, $\mathrm{P}=$ Effect of protein amount, $\mathrm{C}=$ Effect of carbohydrate amount, $\mathrm{P} \times \mathrm{C}=$ Effect of interaction of protein and carbohydrate, $\mathrm{R} \times \mathrm{CT}=$ Restrict vs control.

${ }^{2}$ Horizontal $=$ Horizontal locomotion. ${ }^{3}$ Vertical $=$ Positive vertical locomotion. ${ }^{4}$ Root mean square error. 
(Bos taurus) in temperate pastures found longer grazing time at 07:00 $\mathrm{h}$ to $11: 00 \mathrm{~h}$ than at 11:00 $\mathrm{h}$ to $13: 00 \mathrm{~h}$. These differences in grazing behavior may be due to animal adaptation, where Nellore (Bos Indicus) is better able to regulate body temperature in response to heat stress than cattle from a variety of B. taurus (Hansen, 2004) and they may have develop different grazing habits.

The greatest difference in grazing time was observed in the 14:00 $\mathrm{h}$ to18:00 $\mathrm{h}$ period, due to the mild temperatures. In the hottest period (10:00 h to14:00 h), both supplemented and non-supplemented animals had a short grazing time. At high temperature, it is difficult to dissipate metabolic heat and a reduction in DM intake occurs (Tucker et al., 2008). In an attempt to keep body temperatures at an appropriate physiologic level, animals change behavior to reduce the heat production and improve heat loss. In tropical conditions, Titto et al. (2011) found a reduction in grazing during the hottest period. However, in attempt to increase the intake of energy and nutrients, animals from the restricted group presented longer grazing time than the other groups, including during the hottest hours. The greatest proportion of grazing time (65\%) occurred in daylight (Table 4). Thus, factors that affect grazing time are more evident in this period. Similarly, Scaglia et al. (2009) observed that $70 \%$ of grazing time occurred in daylight.

Supplement intake reduces grazing time (Casagrande et al., 2011), but the intensity of the reduction is a function of the amount ingested (Scaglia et al., 2009) and CP content (Krysl and Hess, 1993). Glienke et al. (2010) found lower grazing time for supplemented animals, corresponding to $1 \% \mathrm{BW}$ of supplement $(7.5 \mathrm{~h} / \mathrm{d})$, in comparison with nonsupplemented animals $(9.0 \mathrm{~h} / \mathrm{d})$. Nonetheless, in this study, grazing time was not affected by supplementation, possibility because the supplement intake was low.

The supplement type (energy or protein) affects pasture and total DM intake (Souza et al., 2010). Although high carbohydrate supplements reduced pasture intake in the present study (Table 3), the total grazing time did not change (Table 4). This corroborated with Casagrande et al. (2011) who found the same grazing time in animals fed energy or protein supplements $(0.3 \% \mathrm{BW})$. This occurred due to many factors that are responsible for feed intake control and even when grazing time is unchanged, feed intake may change.

The fact of the restricted group had shorter horizontal locomotion than the other groups (Table 5) even though they had a longer grazing time may be due to the restricted group being located in a small paddock and paddock size may affect walking distance (Brosh et al., 2010) and grazing behavior (Hunt et al., 2007). In large plots each individual has a wide area to explore and to select forage, but this exploration and selection increases daily activities resulting in longer walked distances which may or may not affect the grazing time.

In a high quality pasture, Brosh et al. (2010) found that total horizontal locomotion distance reached a maximum of 3,550 m/d. However, Johnson and Ganskopp (2008), studying cows in large plots, found a total horizontal locomotion distance of 7,700 m. Daily locomotion distance varies widely and depends on many factors such as land conditions, slope, plot size, forage, supplementation and animal type.

Aharoni et al. (2009) observed that speed was seldom higher than $2 \mathrm{~km} / \mathrm{h}$. In agreement, Brosh et al. (2010) found average horizontal locomotion speed of $208 \mathrm{~m} / \mathrm{h}$ for grazing and $1,813 \mathrm{~m} / \mathrm{h}$ for walking, whereas, Baldivieso et al. (2012) found speed between 150 and $300 \mathrm{~m} / \mathrm{h}$. However, average vertical locomotion speed oscillated between 9.5 and $36 \mathrm{~m} / \mathrm{h}$ in the study of Brosh et al. (2010). In this study, average horizontal locomotion speed was $319 \mathrm{~m} / \mathrm{h}$, which is evidence that grazing cattle usually move slowly.

\section{CONCLUSIONS}

Use of activity sensor methods is recommended for recording time spent grazing and positioning since it present similar data from visual observation, can record 24$\mathrm{h}$ data per day and it is less labor intensive. Daytime grazing correspond about $70 \%$ of total grazing time. The type of supplement (relation protein and carbohydrate) do not change total dry matter intake during rainy season. However, supplement with high carbohydrate decreases pasture intake, but does not affect grazing time and locomotion distances. Moderate supplementation (until $50 \%$ of protein requirement and $30 \%$ of energy requirement) of beef cattle on tropical pasture has no effect on daily locomotion. However, mass of forage affect animal locomotion.

\section{ACKNOWLEDGEMENTS}

The authors wish to thank the Conselho Nacional de Pesquisa e Desenvolvimento Científico e Tecnológico (CNPq) for financial support.

\section{REFERENCES}

Association of Official Analytical Chemists 1990. Official methods of analysis, 15th edition, AOAC Arlington, VA, USA.

Baldivieso, H .L. P., S. M. Cooper, A. F. Cibils, M. F. Pagán, K. Udaeta, and C. M. B. Rubio. 2012. Detecting autocorrelation problems from GPS collar data in livestock studies. Appl. Anim. Behav. Sci. 136:117-125.

Bargo, F., L. D. Mulher, E. S. Kolver, and J. E. Delahoy. 2003. Production and digestion of supplemented dairy cows on 
pasture. J. Dairy Sci. 86:1-42.

Baudracco, J., N. L. Villalobos, C. W. Holmes, and K. A. Macdonald. 2010. Effects of stocking rate, supplementation, genotype and their interactions on grazing dairy systems: a review. New Zealand J. Agric. Res. 53:109-133.

Brosh, A., Z. Henkin, E. D. Ungar, A. Dolev, A. Orlov, Y. Yehuda, and Y. Aharoni. 2006. Energy cost of cows' grazing activity: The use of heart rate GPS methods for direct field estimation. J. Anim. Sci. 84:1951-1967.

Brosh, A., Z. Henkin, E. D. Ungar, A. Dolev, A. Shabtay, A. Orlov, Y. Yehuda, and Y. Aharoni 2010. Energy cost of activities and locomotion of grazing cows: a repeated study in larger plots. J. Anim. Sci. 88:315-323.

Carloto, M. N., V. P. B. Euclides, D. B. Montagner, B. Lempp, G. S. Difante, and C. C. L. Paula. 2011. Desempenho animal e características de pasto de capim-xaraés sob diferentes intensidades de pastejo, durante o período das águas. Pesq. Agropec. Bras. 46:97-104.

Casagrande, D. R., M. V. Azenha, A. L. S. Valente, B. R. Vieira, M. H. Moretti, A. C. Ruggieri, T. T. Berchielli, and R. A. Reis. 2011. Canopy characteristics and behavior of Nellore heifers in Brachiaria brizantha pastures under different grazing heights at a continuous stocking rate. Rev. Bras. Zootec. 40:2294-2301.

Celaya, R., R. Benavides, U. García, L. M. M. Ferreira, I. Ferre, A. Martínez, L. M. Ortega-Mora, and K. Osoro. 2008. Grazing behaviour and performance of lactating suckler cows, ewes and goats on partially improved heathlands. Animal 2:18181831.

Distel, R. A., E. A. Laca, T. C. Griggs, and M. W. Demment. 1995. Patch selection by cattle: maximization of intake rate in horizontally heterogeneous pastures. Appl. Anim. Behav. Sci. 45:11-21.

Figueiras, J. F., E. Detmann, M .F. Paulino, T. N. P. Valente, S. C. Valadares Filho, and I. Lazzarini 2010. Intake and digestibility in cattle under grazing supplemented with nitrogenous compounds during dry season. Rev. Bras. Zootec. 39:13031312 .

Ganskopp, D. C. and D. W. Bohnert. 2009. Landscape nutritional patterns and cattle distribution in rangeland pastures. Appl. Anim. Behav. Sci. 116:110-119.

Glienke, C. L., M. G. Rocha, D. Roso, L. Pötter, V. G. Costa, and J. M. Machado. 2010. Ingestive behavior and displacement patterns of beef heifers on Italian ryegrass pasture. Rev. Bras. Zootec. 39:247-254.

Gontijo Neto, M. M., V. P. B. Euclides, D. Nascimento Júnior, L. F. Miranda, D. M. Fonseca, and M. P. Oliveira. 2006. Consumo e tempo diário de pastejo por novilhos Nelore em pastagem de capim-tanzânia sob diferentes ofertas de forragem. Rev. Bras. Zootec. 35: 60-66.

Gregorini, P., M. Eirin, R. Refi, M. Ursino, O. E. Ansin, and S. A. Gunter. 2006. Timing of herbage allocation in strip grazing: Effects on grazing pattern and performance of beef heifers. J. Anim. Sci. 84:1943-1950.

Handcock, R. N., D. L. Swain, G. J. B. Hurley, K. P. Patison, T. Wark, P. Valencia, P. Corke, and C. J. O'Neill. 2009. Monitoring animal behavior and environmental interactions using wireless sensor networks, gps collars and satellite remote sensing. Sensors 9:3586-3603.
Hansen, P. J. 2004. Physiological and cellular adaptations of zebu cattle to thermal stress. Anim. Reprod. Sci. 82:349-360.

Hodgson, J. 1990. Grazing management: science into practice. Longman Scientific \& Technical, Harlow, UK.

Hunt, L. P., S. Petty, R. Cowley, A. Fisher, A. J. Ash, and N. MacDonald. 2007. Factors affecting the management of cattle grazing distribution in northern Australia: Preliminary observations on the effect of paddock size and water points. Rangeland J. 29: 169-179.

Johnson, D. D. and D. C. Ganskopp. 2008. GPS collar sampling frequency: effects on measures of resource use. Rangeland Ecol. Manag. 61:226-231.

Krysl, L. J. and B. W. Hess. 1993. Influence of supplementation on behavior of grazing cattle. J. Anim. Sci. 71:2546-2555.

Mertens, D. R. 2002. Gravimetric determination of amylase treated neutral detergent fiber in feeds with refluxing in beakers or crucibles: Collaborative study. J. AOAC Int. 85: 1217-1240.

Ramseyer, A., A. Boissy, B. Thierry, and B. Dumont. 2009. Individual and social determinants of spontaneous group movements in cattle and sheep. Animal 3:1319-1326.

Shingu, Y., M. Mori., H Nakatsuji, S. Kondo, and K. Umemura. 2012. Effects of moving inclination on heart rate of lactating cows during grazing on an inclined pasture. Nihon Chikusan Gakkaiho 83:47-56.

Scaglia, G., H. T. Boland, and W. E. Wyatt. 2009. Effects of time of supplementation on beef stocker calves grazing ryegrass. II. Grazing behavior and dry matter intake. Prof. Anim. Sci. 25:749-756.

Souza, M. A., E. Detmann, M. F. Paulino, C. B. Sampaio, I. Lazzarini, and S. C. Valadares Filho 2010. Intake, digestibility and rumen dynamics of neutral detergent fiber in cattle fed low-quality tropical forage and supplemented with nitrogen and/or starch. Trop. Anim. Health Prod. 42:1299-1310.

Titto, C. G., E. A. L.Titto, R. M. Titto, and G. B. Mourão. 2011. Heat tolerance and the effects of shade on the behavior of Simmental bulls on pastures. Anim. Sci. J. 82:591-600.

Trotter, M. G., D. W. Lamb, G. N. Hinch, and C. N. Guppy. 2010. Global navigation satellite system livestock tracking: system development and data interpretation. Anim. Prod. Sci. 50:616623.

Tucker, C. B., A. R. Rogers, and K. E. Schütz. 2008. Effect of solar radiation on dairy cattle behaviour, use of shade and body temperature in a pasture-based system. Appl. Anim. Behav. Sci. 109:141-154.

Ungar, E. D., Z. Henkin, M. Gutman, A. Dolev, A. Genizi, and D. Ganskopp. 2005. Inference of animal activity from GPS collar data on free-ranging cattle. Rangeland Ecol. Manag. 58:256266.

Ungar, E. U., I. Schoenbaum, Z. Henkin, A. Dolev, Y. Yehuda, and A. Brosh. 2010. Inference of the activity timeline of cattle foraging on a mediterranean woodland using GPS and pedometry. Sensors 11:362-383.

Valadares Filho, S. C., P. V. R. Paulino, and K. A. Magalhães 2006. Exigências nutricionais de zebuínos e tabelas de composição de alimentos BR-CORTE. Editora UFV, Viçosa, MG, Brazil.

Valente, É. E. L., M. F. Paulino, E. Detmann, S. C. Valadares Filho, L. V. Barros, T. S. Acedo, V. R. M. Couto, and S. A. Lopes 
2011a. Levels of multiple supplements or nitrogen salt for beef heifers in pasture during the dry season. Rev. Bras. Zootec. 40: 2011-2019.

Valente, T. N. P., E. Detmann, A. C. Queiroz, S. C. Valadares Filho, D. I. Gomes, and J. F. Figueiras. 2011b. Evaluation of ruminal degradability profiles of forage using bags made from different textiles. Rev. Bras. Zootec. 40:2565-2573.
Valente, E. E. L., M. F. Paulino, E. Detmann, S. C. Valadares Filho, and S. A. Lopes. 2013. Performance of young bulls supplemented with different relation of protein and carbohydrate from suckling phase until slaughter in tropical pasture. J. Anim. Plant Sci. 18: 2711-2722.

Williams, C. H., D. J. David, and O. Iismaa. 1962. The determination of chromic oxide in feces samples by atomic absorption spectrophotometry. J. Agric. Sci. 59:381-385. 